\title{
A CRITICAL LEGAL ESSAY TO ADVOCATE IRANIAN CHILDREN'S RIGHT TO "PROPER" EDUCATION
}

\author{
FATEME BOSTANI*
}

\begin{abstract}
This article aims to create a critical legal essay to answer the main question of how to help Iranian governance in improving the respect of children's right to "proper education"? The concept of the "right to proper education" serves the Iranian children's right to education more consistently with the very sociocultural-Islamic context of this developing country rather than an allegedly occidental form of right to education. To create such an approach, we have combined a critical view to the Iranian legal system, as well as a sociological view to the Iranian educational system, while benefiting the philosophical results of an inquiry on virtue ethics and Islamic education. Finally, this critical legal essay suggests the Iranian governance to be open to a shift toward a modern contractual authority in the educational system to be more compatible with the psycho-emotional needs of children and at the same time to apply the virtue ethics' political advice to move toward a liberal form of educational policies that promotes the virtues of autonomy and toleration.
\end{abstract}

Keywords: Children's right to education, Islamic Republic of Iran, interdisciplinary and critical essay, Iranian educational system, Iranian-Islamic legislative governance, social representation of children's rights, elementary school in Iran

Summary: 1. Introduction. 2. Step One: The Actual Condition of Children's Right to “Proper Education" IN IRAN. 2.1. Some Observed Problems in Iran's politico-legal and educational system. 2.1.1. Iran's Public Policies Deficiency regarding Children's Rights. 2.1.2. A View to the Iranian Legal System regarding the Children's Rights Protection. 2.1.3. Traditional Mode of Authority in the Iranian Educational System. 2.2. The Iranian Socio-Cultural features to be considered for any Potential Improvement. 2.2.1. Iranian Pro-Democratic Movement. 2.2.2. Islamic Educational System in Iran. 2.2.3. The Modern and Enlighted Interpretations of Islam in Iranian Intellectuals. 3. Step Two: Social Representations of Children's Rights in Iran through the Empirical Results. 3.1. Overlooking Children's Rights in Iranian Public Policy. 3.2. Empirical Occurrences Related to the Traditional Authority in School. 3.3. Pro-Democratic Social Representation in Iranian Elementary Schools. 3.4. A Naturally and Unavoidably Embeddedness of "Human Rights Social Representations" in Islamic Culture of Iranian. 4. Step Three: Suggestions for Iranian Governance to Move toward a Better Protection of Children's Right to "Proper Education”. 4.1. First Proposal: Contractual Pedagogy to Overcome the Traditional mode of Education. 4.1.1. Characteristics of Contractual Authority in the Educational System. 4.2.1. Islamic Education connected to Virtue Ethics as an Aim-Talk for Iranian Educational System. 4.2.2. The Contribution of Virtue Ethics in Educational Public Policies of Iran to Achieve the "Proper Education"

\footnotetext{
* L.L.D, Faculty of Law, University of Montreal, fateme.bostani@umontreal.ca

** As this article is the fruit of my PhD thesis in the faculty of law, University of Montreal, I would like to thank my supervisor, Prof. Violaine Lemay, for her significant role and continuous support in developing this interdisciplinary project.
} 


\section{INTRODUCTION}

This is a critical legal essay for the benefit of the Iranian legislative should desiring to better support the right to education for his children; not only the right to attend an educational program, neither just following the allegedly occidental right to an education that comes from international documents, but it is a concept of education that is consistent with its very own socio-cultural context. In this essay, we call this concept "the right to proper education" and the main question to be answered is how to help the Iranian governance to offer such protection (benefiting from the proper education) for Iranian children? for which we will need to observe the socio-legal deficiencies and the sociocultural features of this society that all should be considered in order to give any further suggestions.

Therefore, on the path of this paper, we will start, in the first step, by reviewing the literature to observe any deficiency in the actual condition of children's rights to education in Iran and also the socio-cultural features of this field that should be taken into account for any potential improvement. Then, in step two, we present the results of a qualitative empirical study ${ }^{1}$ on social representations of the children's right to education in the field of Iranian elementary school that is extracted from more than eighty semi-structured interviews with Iranian students, teachers, and parents following Kaufmann's method (1996). Finally, in step three, we will come up with suggestions for the Iranian legislative. In this regard, we are aiming not just the right to education, but the right to a "proper" education based on ethical and philosophical grounds in the sense that it would suit Iranian culture and social habits better than an allegedly "universal" [occidental] classical legal conception.

This interdisciplinary piece of research that is an atypical form of legal writing will use the result of a classical review study on the Iranian legal system as well as an empirical study on the children's rights in the educational system of this society and finally by using a philosophical view to this issue from the virtue ethics theory, will enrich the field of public law in an innovative way suggested by Jean Francois Gaudreault DesBiens (2010) called "l'essai en droit" ("the essay in law"). A critical and creative jurist would let the doors of interpretation and interaction open to social science to achieve what Jean Francois calls "faire du droit" (doing or creating the law). We humbly claim to actualize the "faire du droit" as our way of doing this research by bringing sociology and philosophy to the assistance of doctrinal law and thereby realizing a new analysis of human rights.

\section{Step One: The Actual Condition of Children's Right to "Proper EdUCATION" In Iran}

To help the Iranian governance in improving towards better protection of children's right to proper education, we found it appropriate first to look for the problems hidden in

\footnotetext{
${ }^{1}$ Fateme Bostani, Children's Right to "Proper Education" in Contemporary Iran: A critical Legal Essay with an Ethical and Empirical Approach towards Improving Iranian Governance (PhD Thesis, Université de Montréal, 2019) [unpublished] at 116-308..
} 
the socio-legal system of this society and also some socio-cultural notions that affect any further move in the development path. In this part, we concentrate on the review of literature and theories that could describe the actual condition of children's rights in the Iranian society while the result of our empirical study comes in the next part -step two-.

\subsection{Some Observed Problems in Iran's politico-legal and educational system:}

\subsubsection{Iran's Public Policies Deficiency regarding Children's Rights}

In Iran - probably like many other countries in the world - the children were not recognized as the right holders until at least 100 years ago. For the first time, in 1923 in one of Iran's provinces, children's labor was banned for girls under 10 and boys under 8 years old. This kind of protecting basic rights of children continued to exist to some extents but the researchers usually recall the Law of protecting children and adolescents (2002) as the turning point where the expression of "child abuse" has been used for the first time in the legal literature of Iran (Ghaffari \& Hosseini 2015).

Therefore, it is not a surprise that the general policies of Iran, either social or legal policies, are still suffering from deficiencies in the field of children's rights, as it is a new concept entering the Iranian socio-legal literature. The traditional point of view about children has existed in this system for a long time and it will take considerable time and effort to change the traditional image of children to the modern one. Let's remember that, for a very long time, hundreds or even millions of years, the children have been usually considered the private properties of their fathers, whose lives have been on some occasions in their hands. To understand the magnitude of the challenge of the child subject of rights, in terms of social change, Violaine Lemay refers to "socio-cultural inertia". She affirms that, according to the sociology of law temporality, social habits do not change immediately despite passing modern legislation to protect the rights of children. It would generally take as long as the age of a social habit to change a social habit even after adopting modern legislations (Lemay 2009). When one keeps in mind that these parts of the world are rather heirs of old civilization and not necessarily inclined to be open to western modernity, one can better understand why the Iranian legal system still suffers from traditional social habits regarding children.

NazerZade Kermani (2009, pp.39-40), in her article “Children's rights: a need for recreation", also emphasizes the fact that Iran's legal regulations about children have been usually based on a traditional look about the children. She says:

"[We] believe that many of the laws regarding the children, including civil or criminal, are not efficient, and in some cases, they are lacking the concept of justice and are harmful to the society. The "traditional view" to the child and childhood, in these laws, could not respond to the needs of "Today's Iranian child". The achievements of civil and rural sociology reveal obvious differences between civil and rural families... It seems that the family law and specifically the regulations about the children are affected by rural/traditional society." 
So she calls for a reconceptualization of "children's rights" in Iran's legal system. This has also been mentioned by another famous children's rights activist and scholar in Iran, Mehrangiz Kar (2005, pp.97-98), who believes that a basic change must take place in the legal system of Iran to fulfill the rights of children and women. She believes that "if we seek the protection of children's rights, it must be declared explicitly in the constitutional law of the country" and continues:

“... but unfortunately, we do not see in any articles of our constitution such an explicit point about the rights of children. The legislations have to be based on Islamic rules... and Islamic rules have never been defined explicitly, so it is open for everybody to interpret Islam regarding his interest... I mean, the need for modifying the laws is vital for the Iranian people like the need for air and water, but the windows of the legal structure are still closed to this change... the authority also does not seem to be intended to finish this condition."

Another research has been done on the issue of children's prostitution and Iran's criminal policy in this regard. The Iranian criminalization of this issue has been criticized in this article while mentioning the need for a more precise legal protection for the vulnerable children. The writer also confirms our critical view in this section by saying that:

"In our country, there is no legal authority, nor any information center, neither a secure place for children to recourse in emergency cases... Despite the prepared legal context, Iran is still too far from the complete implementation of the Convention on the Rights of Children... and the most reasons for this condition go back to the government.1) Iran has accepted the CRC conditionally. 2) In Iran's civil law some articles easily neglect the rights of children. 3) The government does not even fulfill its duty of protecting children's rights to some extent that have been accepted by its internal laws; such as educating kids and families, recognizing the child as a dependent person, [and] paying enough attention to the state of the family." (MirFardi 2017, pp.125-128)

The political executors of this sphere also mention such a problem when they face children's affairs dilemmas. For example, Sajjadi, the vice president of Iran in the women and family's affairs, in an interview (IRIB NEWS AGENCY, 2018), emphasizes that the current laws are not child-oriented and this is the most important deficiency in protecting children's rights. She also stresses the recent character of women's and children's rights in the country:

"Although improving the health and stability of families are the policies of the government, unfortunately, paying attention to children's rights is less visible in our country. We could see this defect all over the legal system since there was not the same concept of childhood in the past periods. The children's rights are very young in our country as well as women's rights. Since two decades ago, by increasing the number of child abuses in society, 
the sensibilities for the children's rights protection have been turned into a common demand."

Sajjadi then mentions some children's rights-violating laws in the Iranian legal system, such as the right of a father to corporal punishment of the child, excluding father from common punishment $\left(\mathrm{Ghisas}^{2}\right)$ in case of murder of his child, the age of criminal liability which is assumed the same as the age of physical puberty ( 9 for the girls and 15 for the boys), etc. She hopes that all these problems get resolved by approving the New Bill of Protecting the Children and Adolescents by the parliament.

There has not been any authority in the field of children's rights in Iran until a few years ago but now there is an institution called the "National Reference of Children's Rights Convention". However, this authority does not have any executive responsibilities and has only some tasks of arrangements and reporting. According to the claims of professional activists in the field of children's rights, this only reference also does not seem to be very efficient. ${ }^{3}$

\subsubsection{A View to the Iranian Legal System regarding the Children's Rights Protection}

The Iranian legal system in many aspects, is respective of fulfilling its duty to protect children's rights: in families, by considering the best interest of the child (Parsapour \& Nourbakhsh 2015); in the educational system, by stating the compulsory education for every child (The law of providing facilities for the education of Iranian children and youth 1974, Article 2) and aiming to provide a happy environment for the students (Executive regulations of schools 2000, Article 98); and facing the criminal cases, by adopting the "law of protecting children and adolescents 2002"; Although this is a good start, there are criticism waves regarding the situation of children in this legal system.

Iran has been one of the first states that ratified the International Convention on the Rights of Child. However, this acceptance was conditional; so the priority of Islamic regulations has been reserved in case of any contradiction. This seems to be a challenging point because in most criticized cases where the Iranian legal regulations fail to fulfill the international duty of children's rights protection, there is an Islamic matter of concern.

The age of childhood is, for example, the most challenging criterion that ends up dismissing some internationally accepted rights of children such as criminal liability of kids under 18 and child marriage. The age of childhood has not been determined clearly in Islamic teachings (only the physical puberty has been mentioned as the criterion for considering the person as an adult, and this age is traditionally considered 9 years old for

\footnotetext{
${ }^{2}$ For a more detailed discussion of his look at: Abdullahi Ahmed An-Na'im, "Human Rights in the Muslim World: Socio-Political Conditions and Scriptural Imperatives - A Preliminary Inquiry" (1990) 3 Harv Hum Rights J 13-52.

${ }^{3}$ This is the idea of Professor Mohammad Mojtahed Shabestari, an Iranian specialist in Islamic hermeneutics and Islamic enlightenment. Mohammad Mojtahed Shabestari, Human Rights will not become Islamic but Muslims should accept it (2017).
} 
girls and 15 years old for boy)( Haidari \& Ghiasi 2013). So, there is always a chance for a misjudgment and also discriminative convictions for persons under 18 (Modavvar 2017).

This is while these Islamic regulations are contradictive even among the Islamic thinkers and specialists. There have been numerous debates on the relationship of Islam with Human rights which usually go under the philosophy of religion and also the science of interpretation (Hermeneutics).

"These problems do not derive from Islam per se but have to do with the Islamic shariah, or more precisely, with traditional or fundamentalist interpretations of the shariah...Given the fact that the basic features of the shariah developed in the first centuries of Islamic history, whereas the historical breakthrough of human rights was roughly a millennium later, differences and conflicts between these two normative systems can be no surprise." (Bielefeldt 2000, pp.102-103)

Therefore, there have been different approaches to integrate the occidental concept of human rights into the fourteen centuries-old Islamic culture either by being essentialist (fundamentalist) approaches or enlightened and more modern interpretations of Islam. The essentialist point of view takes Islam as the source of an ideal life for human beings and tries to adopt human rights norms only when they are compatible with Islamic regulations. The Cairo Declaration of Human Rights in Islam (1990) could be an example of such an approach because Muslim states found the Universal Human Rights Declaration incompatible with Islamic rules in some points and tried to give an Islamic version of Human Rights. Although this declaration uses a universal language of rights, it still mentions Islamic Shari'a as the only source of given rights in the declaration. Like when the introduction of "The Universal Islam Declaration of Human Rights (1981) states "fourteen hundred years ago, Islam gave to humanity an ideal code of human rights", so they never leave any opening for a contemporary interpretation adapted to modern life of Muslim people.

This is while the enlightened approach tries to present an interpretation of Islam that is compatible with the Universal Human Rights regulations. Abdulahi Ahmed An$\mathrm{Na}$ 'im is an example of the Islamic thinkers who believe that despite the real inconsistency between shari'a and Human rights, there could be an interpretation from the Quran to be compatible with these universal regulations because the core of Islam is also based on equality and human dignity. ${ }^{4}$ Some points of view make a distinction between these two phenomena (Islam and Human Rights) and believe that, even though Human Rights cannot be Islamic by definition, Muslim societies have to accept human rights rules as the essence of modern social life. ${ }^{5}$

\footnotetext{
${ }^{4}$ The basic punishment of slaughter in Iran's legal system is Ghisas which means that the same thing should happen for the crime committer i.e. death penalty in case of killing someone.

${ }^{5}$ Referring to the experimental results on "children's rights social representation in Iranian Elementary schools" which are used in this article.
} 
Despite these contradictive ideas about the relationship between Islam and human rights, it seems that the Iranian legislator has taken a traditional interpretation of Islam into account at least where it comes in contradiction to the international human rights regulation such as what we mentioned earlier about the age of childhood.

\subsubsection{Traditional Mode of Authority in the Iranian Educational System}

One considerable conclusion that could be extracted from the observed field (Iranian elementary schools) is the fact that what we call here a phenomenon of social pregnancy of a "traditional model of authority" (according to Gérard Mendel theories applied to the general educational field by Violaine Lemay 2005) which seems to be existing in the educational system of Iran. In other words, the relationship between teacher-student or parents-students still follows a rather traditional order of power (authority) where the superordinate party (the adult) does not share any bit of autonomy, responsibility, or useful knowledge with the vulnerable (the child).

According to Violaine Lemay (2005, pp.151-152), what would be called "psychological modernity" seems to be an inescapable event of the occidental world. It has been discussed extensively in her Ph.D. thesis on "pedagogical contract" in which she explains how the form of authority over the child changes in this shift:

"The advent of psychological modernity, the germ of which can be traced back very far, but whose theorization could only emerge with the genesis of the whole new consciousness of the self (ego) and its science (psychology), thus appears. as a change in the way of dealing with the ancient intergenerational subordination and, by extension, the asymmetry incompetence between people. In traditional society, the elders found themselves in a position of strength since, through experience, they had acquired the knowledge necessary for survival. The youngest children, deprived of this knowledge, needed the protection of the group to survive. The ancient and crude balance of power imposed the subordination of people in a position of socio-cognitive weakness.»»

Lemay focuses on the analysis of educational authority. A fact catches her attention. In the twentieth century, social work, psychology, and, more recently, pedagogy appear to be the three similar theories of intervention: these three theories that call themselves "contractual" (some without the knowledge of others) because they prescribe to the holder of power the same rules of relational sharing: 1-do not decide only based on your own idea (share ideas) 2-do not decide everything alone (share autonomy); 3- do not look at each other as unworthy to explanation (share information); 4-do not look at yourself as the sole responsible (share obligations). These four are praised in their respective disciplines because of their spontaneous "clinical adherence": in other words, when the authority holder exercises power according to this model, his subordinates not only adhere to his orders but seek his command. That is the reason this movement is now strong in the health systems, at the root of the "patient expertise" growing around the world (for example Lemay et al. 2017). 
Let us note that this concept - contractual authority - is in many ways similar to that of assabyyia as the concept which is used by the great Muslim author, Ibn Khaldun (1332-1406).

«Assabiya is translated as clan spirit, public spirit, and even social capital. It refers to a psychological force that unites the members of several clans and gives them the possibility of accessing power. »(Nablia 2011, p.114) [...] « I say there is no power without "assabiyya". [...] It is the crux of my whole social and political theory, even my whole view of civilization and history. "Assabiyya" is at the heart of power, and power is at the heart of the functioning of society and the development of civilization... » (Cheddadi 2016, p.145)

This notion once again reveals the prognostic character of this great Muslim author, who is still and sadly not yet widely known in the West. A bit like Mendel and Cyrulnik at Lemay, who wrote in the twentieth century, he had the intuition of common anthropological traits explaining peoples' adherence to certain powers and the impact of this adherence on the destiny of collective relations.

Observing the elementary schools of Islamic-Iranian society reveals a very close connection with the psychoanalytic theory of Mendel and also those of Ibn Khaldun. This notion will be more presented in the empirical study of this research (Step two). While an existing "archaic" model of power fails to fully respect the rights of children in the educational system of Iran, a socio-political change towards the "contractual authority" would be a survival path for the future generation of this society by paying more attention to the development of psychology and the psycho-emotional needs of children.

\subsection{The Iranian Socio-Cultural features to be considered for any Potential Improvement}

In this section, it is now time to look for the actual potentials of the field research that could help us achieve our goal. Here, we ask ourselves whether any potentials have been observed in Iranian society to be considered as the opening point toward a change. While the goal is to find an adaptable version of children's right to education to the sociocultural context of Iranian society and to approach the respect of kids' "right to proper education", considering the socially embedded elements would be undeniable. We will present three significant notions in this regard: first is the pro-democratic movement and social representation of high demand for human rights implementation and secondly the fact that this high desire for human rights protection is naturally and unavoidably attached to the Islamic concept of the good life because of the Islamic educational system that has a long history in this society. However, a modern and enlightened interpretation of Islam exists in the Islamic Iranian literature which could be a matter of emphasis for further improvements.

\subsubsection{Iranian Pro-Democratic Movement}

Iran's history through the last century has been full of attempts toward establishing social and political modern elements, especially democracy. As a country 
with a long historical experience of over 2000 years of dictatorship, adopting the new concept of the state, that supposedly would present the power to the people rather than the unquestionable authority of the kingdom, was not an easy step, considering the significant role of Islam and clergy in the socio-cultural context of Iran during the times. Therefore, several attempts have been made to theorize such a reform that could be categorized under: a very minimalistic democracy, a secular democracy, or a religious democracy (Akbari 2003, p.70).

Jalaiipour (2004, p.192) mentions, there have been four significant waves of demand for democracy in Iranian contemporary history. While for the first time people tried to limit the authority of the kingdom by the Rule of law (The Constitutional Revolution, 1906), the second time was during the prime minister Mosaddegh by Nationalisation of Iranian Oil Industry and then by the Islamic Revolution(1978) that ended finally the thousands years old monarchy. However, the presidential election of Khatami in 1997 was the most important recent movement toward the democracy demands of Iranians, which is called the Reform movement (Ravanestan 2017).

After the reform movement, the socio-political groups in Iran started to develop democratic and civil norms in which the concepts of civil society, pluralism, democracy, dialogue, tolerance, competition, participation, etc. were the main principles. Despite all these political efforts to open the society to democratic views and the emergence of civil society, the process of passing towards democracy in Iran has always been faced with ideological obstacles that ended up in some failures in this path (Bashiriyeh 2008, p.99). However, the current desire of the Iranian people to democracy which is the result of many socio-political expenses paid by this nation is promising by itself (Homayoun Katouzian 1993, p.20).

After all, even though the Iranian people's desire for democracy has still difficulties getting actualization, what remains to be found by them is their proper pattern of democracy consistent with their national-Islamic identity and their geopolitical condition.

"After passing through the fruitful historical experiences that happened to Iranians, this nation has come to this conclusion that to sustain its existence among the changing $21^{\text {st }}$-century geopolitics of the world, it has no other way other than high steps towards a domestic democracy... It is now clear for all the nations that democracy[...] is not a luxury gift cloth for which the body of nations must be carved. It is rather a not-sewed cloth which will be sewed only by the hands of those nations and for their very own cultural body." (Mojtahedzadeh 2007 p.104)

Let us here focus on the latter words of this quotation... "Domestic democracy $[\ldots]$ is rather a not-sewed cloth which will be sewed only by the hands of those nations and for their very own cultural body". One could not better express the critical global approach of this legal essay.

However, social demand for democracy and human rights in this society seems not to be detachable from the Islamic concept of the good life that they have been taught 
through the ages of being under the effect of Islamic culture. This is what we will see in the next section.

\subsubsection{Islamic Educational System in Iran}

A factor that plays a significant role, in forming an Islamic social representation of human rights in the elementary schools of Iran, is the fact of an Islamic educational system, for which the roots could also be found in the religious-based education in this country through the times.

The studies on the history of education in Iran have found religious-based education for the kids even in the pre-Islamic period. Iranian were Zoroastrian ${ }^{6}$ in that time and were educating their children at home or in the fire temples principally regarding morality and religion (Sohbatloo 2008).

The children's education method continued to be almost the same after Islam came to the scene of history. The kids used to be gathered in some individual's houses and after a while in the Mosques ${ }^{7}$ to learn reading, writing, and moral/religious lessons all according to Islamic teachings and using Islamic sources especially Quran (Takmil Homayoun 2002).

This traditional form of education continued to exist for centuries so that education became kind of restricted to religious education and in the hands of the Clergy. This was the case until the age of the Qajar dynasty that started the project of modernization in Iran. Their attempt to initiate modern schooling was opposed by clergy as they believed that it will be an anti-Islamic or de-Islamization project. However, in 1851 finally, a modern high school called Daar o l Fonoun (Polytechnic high school) was founded in Tehran which was designed with the western methods of training. Daar o 1 Fonoun became an inspiring institution for the Pahlavi ${ }^{8}$ dynasty to continue the educational reform attempts that included a kind of de-Islamization of schools and curriculums (Tamer 2010).

Iran has experienced two contracting policies before and after the Islamic revolution in 1978 which were mainly de-Islamization before the revolution and Islamization afterward. This change unavoidably affected the elementary education system and curriculum in which the policy-makers had the plan to build up the future society. Zarean (1998, pp.273-274) states that, after the revolution, the concepts of Nationalism, westernization, pre-Islam values, and secularism were totally refused:

\footnotetext{
${ }^{6}$ "The interviewer, in this research project, has been succeeded to make as many as 87 interviews in the field of elementary schools of Iran. The interviewees consisted of 61 students ( 32 boys and 29 girls), 2 parents (2 mothers), 23 teachers (6 oral interviews and 17 questioners), and one children's rights activist." Authors' name, Supra note 1 at 267.

7 "Right to Play and Run: A Crucial Right Coming from a Natural Need": Ibid at 198-202.

8 "Under the Security Cameras: Imposing the Sense of Being Controlled All the Time", Supra note $i$ at 205-207.
} 
"From the very beginning of the first year of the elementary cycle, the students in the Islamic Republic begin to learn about Islam from different directions. While they learn spiritual and moral aspects in an individual domain, they learn how to apply these values in their social and even political life. At the same time, they are trained to oppose those pre-Revolutionary values that were magnified by the Pahlavis and still, to some extent, are evident in society."

The religious, ideological, and political tendencies in elementary education are obvious in the document of "Aims of elementary education", approved on May eighteen 2005 , according to which the student at the end of elementary school (11 years old) should believe in the principles of Islam, should have to respect the Islamic rules regarding the relationship with counter sex, should be interested in religious governing and be aware of Islam's contemporary enemies and also be familiar with the concept of "National security"! (Mansoori Boroojeni 2011)

No wonder when we ask very young children what they think of respecting people's rights, their reaction comes up with a divine normative structure that will punish them if they become cruel to others so they try to make friends with the classmates to achieve the satisfaction of God. All historical culture in which those children live is embedded in a normative approach to Islam.

We tried to clarify to some extent the social and historical context of religious education in Iran in which the religious common sense of "rights" is not detachable from the Iranian Islamic concept of "being a good human being" or the essence of the "good life" as one of the most important results extracted from the field. Let us now observe a modern approach to Islamic views which is more compatible with human rights regulations.

\subsubsection{The Modern and Enlighted Interpretations of Islam in Iranian Intellectuals}

One could observe the specific approach of Iranian intellectuals to the Islamic culture which is far from the conservative interpretation of Islam and seems to be compatible with human rights recognition.

It is a matter of consideration how Iranian, with a long and rich Persian cultural history, faced Islam at one point and accepted it whether under the force of sword or because of their social contextual need. It is also interesting how Islam little by little became part of Iranian culture and created an Islamic-Iranian identity. And suddenly in the age of modernity, they faced the occidental concept of human rights and tried to adapt it into their culture along with the project of modernity. Well, it is certainly a complex social process and shows what the children and teachers are talking about seems to us not detachable from what the Iranian society has experienced.

However, it could be said that Iran's Islamic Revolution in 1978 was a reaction to the de-Islamization policies of the ruling power in Iran during the two last dynasties 
(Qajar and Pahlavi ${ }^{9}$ ) which were trying to bring modernity to Iran's society and used to see Islam as a barrier to this process. Zarean believes that although the tendency of Iranian society to oppose this de-Islamization combined with the socio-economic challenges of the time, turned finally to the Islamic revolution, the political efforts in eliminating Islam from the society and emphasizing the Persian nationality had its effects (Zarean 1998). Therefore, in contemporary Iran, neither the Nationalist nor the Islamic aspects of Iranian Identity cannot be neglected.

The other significant period in Iran's process of modernization especially in socio-political enlightenment was after the presidential election of Mohammad Khatami in 1997, who was representing the reformist approach in politics. He claimed freedom in the society and came up with the suggestion of dialogue amongst civilizations in the UN. ${ }^{10}$

The religious enlightenment, then, spread up in the Islamic academic sphere of Iran and the intellectuals tried to theorize the adoption of concepts of secularism, democracy, and human rights in the Islamic culture of Iran. Among them, Abdolkarim Soroush is one of the most well-known enlightened thinkers and writers. His specific contribution to new interpretations of Islam was "theoretical contraction and expansion of the shari'a" (2009) according to which Islamic jurisprudence must follow rational theology, involving the constant reinterpretation of Islam following the growth of knowledge outside of religion, particularly in science and philosophy.

Soroush's ideas on democracy, secularism, and human rights have been criticized by Islamic fundamentalists in Iran, especially the political power, but his tremendous effect on the modern understanding of the Iranian society of Islam is unquestionable. However, he believes that in the challenge of religion, tradition, modernity, and political secularism, the crisis of Iranian culture must be acknowledged and remedied through harmonizing and rational efforts (Matin-asgari 1997).

In sum, one could follow the process of the bilateral identity of Iranian society with all its ups and downs through time but still, the Islamic and nationalist aspects have not been separable.

Having reviewed the two significant features of Iranian society — the prodemocratic social representations and Islamic embeddedness in the concept of human rights - and because an enlightening stream in the interpretation of Islam is growing in this country, we should now look for the specific suggestions for the Iranian governance to approach a concept of children's right to "proper education" which is consistent to its very own Islamic-Iranian identity. The next step will discuss this question.

\footnotetext{
9 “'I [Should] Have the Right Not to Go to School!': The Children's Expression of Disgust and the Extent of the Right to Do Wrong", Supra note $i$ at 236-237.

10 “'Kids' Rights Are Not Respected at Home, How Do You Expect It to Be Respected at School?!': The Problem of Violence against Children", Supra note $i$ at 224-227.
} 


\section{Step Two: Social Representations of Children's Rights in Iran THROUGH the EMPIRICAL Results}

The empirical material (the content of the interviews coming from qualitative sociological research in Iranian elementary schools ${ }^{11}$ ) is another source to be observed and analyzed in this critical interdisciplinary essay. In this part we turn now to our empirical results to see what weaknesses and deficiencies this field can reveal regarding the children's right to "proper education"? and what are socio-cultural features should be considered for further suggestions and potential improvements?

The observed social representations give us a good idea of what difficulties this society can face according to the social representations of children's rights in the elementary schools, such as what we call a "traditional form of authority" in the educational system of Iran and also an overlooking approach to the rights of children in the public policies. Moreover, the observed pro-democratic social representation in Iranian elementary schools and also the natural embeddedness of human rights social representations in the Islamic culture of this society should be taken into account in responding to the question of this research.

\subsection{Overlooking Children's Rights in Iranian Public Policy}

One of the extracted ideas of our empirical field is the observed social representation of the public policy of Iran regarding children's rights which indicates the interviewees' unhappiness about the general social policies of the society about children's rights.

Occurrence \#1: We observed a very general disappointment of people regarding the respect of children's rights in society; a negative reaction from the interviewees when they have been asked about children's rights conditions in Iranian schools. ${ }^{12}$ They presented either an unawareness of the rights of kids or complaining about not being respected.

"I have no idea about children's rights and it is not only me. I would say the society is not aware of that." (Mehrnaz, teacher of $2^{\text {nd }}$ grade) "There are many types of discriminations in our educational system: religious, linguistic, and gender discrimination. We receive many reports on the sexual abuse of children." (Mastaneh, children's rights activist)

The observations in our field show common sense among the people of negligence about children's rights, or even more generally, human rights in Iran's society. People who are directly in contact with children - being either the parents, teachers, or children's rights activists - do not believe that the public policy of the country is working in favor of protecting children s rights.

\footnotetext{
11 'The Society Is Not Aware of Children's Rights': The Common Belief of People about Lack of Respect for Children's Rights", supra note $i$ at 243-244.

12 "Early Sexual Abuse Experience at School: An Obvious Need for Security and Education", Supra note $i$ at 233-235.
} 
One could say that a common dissatisfaction about the condition of human rights in this society is not a matter of surprise because the lack of free expression and free media in Iran does not let the people be in the real stream of news and facts which are happening around them. They cannot trust the official statistics as they have a feeling that the truth is being hidden from them. So each time they hear disastrous news about the children, they conclude that there must be even something worse. They extend their unhappiness about their own condition to everything related to governmental policies. The general distrust amongst people and political power causes a generally negative view about the exercise of human rights in society.

Occurrence \#2: The sexual security of children is a very important subject of social policies which has been discussed in our empirical analysis. ${ }^{13}$ How could a mother, whose son has experienced sexual abuse in the very first grade of public elementary school, trust the social and political efforts of the public power anymore? The problem gets worse when we observe the fact that people usually keep silent when they face such abuses, so the statistic around this issue is never an accurate one. This is another problem identified by V.Lemay (2009) as an indicator of social inertia in favor of habits of no limited power of the adult on the child. For example, when the common sense still approves the jurisdiction of the father on the child, and the idea of the child only as of the object of law still exists, the public denunciation of the pedophile father is highly unlikely: isn't his family jurisdiction sacred and legitimate? Isn't the child his property? Then it stays untouched immemorial law of silence. In contemporary Iran, there seems to be no education toward protecting children from sexual abuse because the public policy of the educational system still believes that these are the red lines for the kids and might mislead them to sexual deviation rather than protecting them.

Occurrence \#3: Another example of dissatisfaction about public efforts to execute children's rights in society has been presented in the issue of children with handicaps in the educational system. ${ }^{14}$ The children with minor and major problems have the right to receive "proper education" but it seems that the social constructions in Iran do not allow them to fully benefit their rights despite the legal protection of handicapped persons' rights. Shirin, the mother of a 10 years old boy, extends her son's experience to the whole society because she does not feel that any solution exists for such a problem in her society. "We don't have such a thing [education separation for children with special needs]! My son had a classmate who used to take lots of pills and used to hit the other students!'(Shirin, 32 years old mother)

Occurrence \#4: The big difference between the quality of education in public and private schools could also be a symbolic sign of deficiency of educational policies in Iran. ${ }^{15}$ Private schools offer a higher quality of education and treatment for students, while

\footnotetext{
13 "Need for Separation and Support of Handicapped Children: An Obvious Part of the Right to Proper Education", Supra note $i$, at 241-242.

14 "Public Schools vs Private Schools in Iran: A Matter of Concern for Educational Justice", Supra note $i$ at 221-223.

15 “The Public Policy’s Deficiency Regarding Children’s Rights Protection”, Supra note $i$ at 231-232.
} 
it is still very difficult for most people to afford the expenses of private schooling for their children. This has also been approved by some quantitative and qualitative researches such as an article that indicates a considerable difference in structural learning between public and private schools. Regarding this empirical research, private schools have a higher quality in all aspects of structural learning compared to public schools (Zarei Matin, Jandaghi \& Moeeni 2003).

It seems that the basic rights of children - sexual security, proper education, and right to their physical integrity (not to get corporal punishment) - are a lot more easily disrespected in public schools rather than in private ones. Why should be such a gap between private and public education that makes the majority of parents and teachers concerned about it? Is this not clear discrimination that seems to be neglected by the policymakers of the educational system? This is even though education in Iran is a centralized matter and all the schools' main structures and curriculum should follow the same system indicated by the central policy of the government. But what happens in the case of quality of education and the resulted discrimination through the high paid/private schools vs. public schools, seems to be abandoned. However on that matter, one could mention that Iran's context of seizure between private and public schools may probably be compared the same to the situation of dozens of other countries.

Occurrence \#5: Finally, another element of the field leads us to the same conclusion of public deficiency. ${ }^{16}$ It comes from the complaining of a children's rights activist about the lack of public efforts in the actual protection of children's rights. "You have an organization for 'promoting the consumption of egg'; what organization do you have for the 'children's rights'?!" she addresses the policymakers and high executors of the country. (Mastaneh, children's rights activist)

This is how the problems of the children's rights in Iranian society could be observed among the social representations of deficiency in the general policies of children's rights in the educational system. As a jurist who is preparing a critical legal essay to help the Iranian governance in this case, these empirical findings would be precious data for implementing a suitable cure. One must be aware of the social problems of an issue to become able to look for the appropriate resolutions. Knowing the most important deficiencies of the Iranian educational system regarding the right to proper education - i.e. traditional form of authority and public policy issues - we could now continue the rational path of suggesting remedies.

\subsection{Empirical Occurrences Related to the Traditional Authority in School}

Having reviewed the theory of Gérard Mendel in the previous part (1-1-3) let us now review some of the empirical occurrences that explain why we relate them to the theoretical authority model presented above.

16 “' Children's Rights Are for the Poor Kids, Not for Me!': Paradoxical Well Understanding of Children's Rights", supra note $i$ at 191-194. 
Occurrence \#1: We observed confusion in understanding children's rights among some teachers. They had a fear of ending up in the "kingdom of children" by recognizing and teaching the children's rights. This fear is the result of a wrong association of the "fundamental rights" for the kids (to be protected against any inhuman violence) and the childish desire not to obey their legitimate parental order. The adults then think that putting a limit to parental authority means necessarily falling into an "all or nothing" process.

When one reflects on this point, it can be linked to the social pregnancy of an archaic understanding of educational authority which cannot imagine any concession to the subordinate (in the sense that no reference would be at all to the "contractual" form of relationship between adults and children.) The teachers and parents seem to believe in a legitimate authority for the adults over the kids that child subject of law would dissolve in a non-sense "kingdom of the child" and then the poles of the vertical relationship between adult and child would be reversed.

Occurrence \#2: In the discourse of the children we met, we observed a very high tendency of children to be free to run and play. ${ }^{17}$ The kids usually complain that they are not allowed to play and have physical activities as they wish. We considered the right to play and run as a crucial right for the children according to their basic need to move and play. Although the children's desire to play and run has been a repeating fact for us to be noticed as their right, a more fundamental reflection leads us to ask why there is so much complaint about that. It reveals, in our idea, the traditional form of psychology which seems to be ruling in the educational system of this society: stronger parties (adults) have power and decide what they prefer without accepting any compromise in satisfying the weaker (children). Just as the time when kids complain about being controlled everywhere in the school by the cameras and feel insecure under this unwanted and sometimes unnoticed control. ${ }^{18}$ It seems the decrease of traditional reign power on children, characterized by a total absence of limit, never even began.

Occurrence \#3: We have mentioned the student's desire to break the rules of school whenever they catch an opportunity and they feel proud because they find the school's rule unjust, not only according to their need but also because they see themselves as subordinates in this authority structure. It goes up to the point when they ask for the right to "not to go to school" 19 , which is not a logical demand in the adult's point of view as they consider education as the means of kid's well-being and flourishing but for a child who is not convinced about what he/she has to do in his/her life, there is always a right to be wrong. The children want to be heard and get involved in everything related to their very own life -childhood-. This type of child resistance to school norms and authority reveals a

\footnotetext{
17 “Disputes around the Students' Association: A Precocity of the Desire for Democracy”, Supra note $i$ at 208-210.

18 "Gender Disparities in Dispute Resolution: Thinking of Gender Dimension of the Proper Education", Supra note $i$ at 216-218.

19 "The Desire to Improve Human Rights Awareness: Teachers and Parents Agree to Teach Human Rights to Children", Supra note $i$ at 245-246.
} 
phenomenon linked to the weak type of educational power or authority, the "archaïc one in Mendel's terms", because of its lack of the effect of clinical adherence that produces a more "modern" one.

Occurrence \#4: According to Mendel, the typical vertical form of the relationship of adults-children starts from the families. That is the fact being observed in our empirical study where the teachers emphasize the role of families in respecting children's rights. ${ }^{20}$ "If the kid's rights are not respected in the families, how do the parents expect them to be respected in the school?" (Atoosa, Teacher of $3^{\text {rd }}$ grad) This teacher - by saying this sentence - does not want to ignore the schools' responsibility regarding the children's rights rather tends to show the significance of the family's role in changing the traditional form of authority relationship settled in the society. The modern psychological reform should happen in the society starting from the families, then we could expect the modernity reform in school's authority relationships actualized from theory to the action.

These observed occurrences in the empirical field that states the existence of a traditional form of authority in the Iranian educational system, should be recognized as a significant deficiency in the Iranian condition of children's right to "proper education" to find the appropriate resolution for this issue. Below, comes the second empirical conclusion illustrating another difficulty in this field.

\subsection{Pro-Democratic Social Representation in Iranian Elementary Schools}

Having observed the field of elementary schools by talking to the children and teachers, we have come to the conclusion which is, despite all the actual difficulties and complaints that exist against respecting children's right to "proper education", a very high tendency and desire to build up a democratic sphere can be seen amongst the students, teachers, and parents.

Occurrence \#1: Among our empirical data we faced a very mature understanding of children's rights concept in some young students ${ }^{21}$. They were aware of the difficult situation of many children in the society who deserve to benefit the children's rights as they do already, like the right to education and not to work in the streets. "[Children's rights] are more for the poor children; the kids who are in the street. They must be helped by the municipality and other [organizations]." By saying this, Ahmad showed his adherence to the idea of the responsibility of state organizations in taking care of children's rights in society. (Ahmad, 13 year-old-boy)

While it is more common for children to care only about their own interests and desires, it seems very impressive to find out that, in this society, the children's understanding and caring about children's rights go beyond their immediate desires. In Canada, maybe

\footnotetext{
20 “Children's Expression of Human Rights Linked to Islamic Concepts", Supra note $i$ at 195-197.

21 "An Islamic Approach in Recognizing the Age of Childhood: Gender Differentiation", Supra note $i$ at $228-230$.
} 
because of the large middle class and reduced gaps between the wealthy and the poor child, children usually do not think about such things as "children left on the street", aspiring to "rights" to protect them. But children in Iranian society can see vulnerable children very closely. It probably explains why they can become concerned about their fundamental rights to live, to educate, to receive food, etc. The ones whom we met, talked about it in a way that presents a certain comprehension that these rights of the children come with the duty of the government to act toward respecting them. Quite interesting when one keeps in mind that we are talking here of mainly prepubescent kids. So we can probably say here that we have a positive human potential here to use in some way if one legislator wants to enforce children's rights.

Occurrence \#2: Another interesting phenomenon showed up in our field of inquiry: the children's desire to political acting toward democracy in the school's area. ${ }^{22}$ It is true that the students complained about the students' association for not being very effective, but is this also not a developed sign of their understanding of what should be expected from a democratic structure?

Every year in almost every elementary school in Iran, an election takes place with all its appliances. The students become candidates and present their plans. They compete in different ways (which may seem very basic and even funny sometimes for the adults though) to attract the other students' vote. They vote and select their representatives, then they expect the association to work for their interests. Yes, they complain sometimes that the association is not beneficial enough...

"We had an election day and voting program for the student association for which the students were very active and excited. It was just like a real election and the students voted regarding the candidates' plan and I think they had proper choices. This is the result of trusting the children and letting them perform their capacity of understanding." (Masoud, social raining teacher)

Regardless of how effective is the association at the end, is this not a democratic practice at the very young ages of childhood? Is this not a call for having democracy in the wider spheres? Is this not a presentation of a social desire for democracy that takes place among the very young generations? Comparing again to the situation of other countries, one can surely ask for the hypothesis of a big difference. In a country where parents and society, in general, do not feel the lack of democratic processes, kids are less likely to inherit from their elders the want of voting and the increasing power of peoples' representatives. In sum and again, we can probably say here that we have a positive human potential here to use in some way if one legislator wants to enforce children's rights.

\footnotetext{
${ }^{22}$ Zoroastrianism was the ancient religion in Iran where the prophet, Zoroaster, emerged and taught people the three main principles of his religion: Good Thinking, Good Talking, and Good Treating. (Pendar 'e Nik, Goftar 'e Nik, Raftar 'e Nik)
} 
Occurrence \#3: We presented a considerable skill amongst the young girls in dispute resolution. ${ }^{23}$ Having observed the girls who were trying to prevent any struggles with their classmates or to resolve peacefully the issues that happen between them, we came to wonder if the concept of peace and friendship was more understood among the society of girls. Could this behavior be an indicator of the women's desire to participate in developing a democratic society respecting peace and human rights? Is the women's general will preparing through their young daughters' acting? We must be vigilant here, being high the risk to take one's desire for reality. But the hypothesis worth being said, as long as it is not purely impossible and then can be, among others, a reason for hope and a potential way to borrow.

Putting aside a women-oriented analysis of a democratic desire in the studied field of Iran, the understanding of some concepts like peace and dispute resolution in the very young children of this society could be a matter of sociopolitical analysis by itself. The kids talk about the concept of peace as a means of "the good life". Even though they refer so often to their religious background on this subject, however, they represent a social desire for peace and human rights in their level of performance.

Occurrence \#4: We asked teachers and parents if they agree to teach human rights to the kids and they mostly answered positively. ${ }^{24}$ The majority of the interviewees seemed to find the idea of teaching such modern concepts to the children not only helpful in their training for the future of the society but also, in some cases, as an essential need for them to be able to be protected from the children's rights violence.

"I am a hundred percent agree to the idea of teaching human rights to children. Everybody should know about his/her rights from childhood through adulthood. Many social issues are the consequence of unawareness." (Farideh, teacher of $3^{\text {rd }}$ grade)

The social representation of the demand for human rights training in the observed fields leads us again to the conclusion that there is a desire in this society to start the reform toward a human rights-respecting sphere where the democratic structure is probably the base.

However, what we have seen in our field as a high tendency of children, teachers, and parents to promote a democratic environment to the extent of their capabilities, must have a root in the bigger society of Iran either as a social or political desire to develop their quality of life to a higher level of democracy and human rights engagement.

Here, we try to show that such a pro-democratic movement has been floated in the Iranian society for a while (by indicating some of its historical, social, and political

\footnotetext{
${ }^{23}$ Later on, the places where the kids used to go for education were called "Maktab" which means a place to read books or a place to learn reading and writing. The education system in "Maktab" were usually very tough for the children. The kids were supposed to learn Quran and also the most important Persian literature books. Physical punishments were a common rule in these small traditional schools (Maktab).

${ }^{24}$ The last dynasty kingdom ruling over Iran before Islamic revelation 1978.
} 
aspects), so observing the same movement in the educational system of this society is not a matter of surprise.

\title{
3.4. A Naturally and Unavoidably Embeddedness of "Human Rights Social Representations" in Islamic Culture of Iranian
}

One of the very noticeable features of Iranian society facing the question of human rights/ children's rights seems to be the Islamic embeddedness concept of "the good life" and "the good human being" in the Iranian culture. This was also a matter of notice in our interviews and observations in the field of elementary schools.

Occurrence \#1: We were asking very young children in the school if they have heard about human rights or people's rights. ${ }^{25}$ Interestingly, we used to get answers linked to religious concepts like God's will and God's reward. The concepts of "equality" and "peace" were straightly defined through God's wish while "fighting" and "being cruel" were toward the Evil's wish and against God's willingness to be a good human being. For the kids of eight or nine years old, this shows that their image of respecting other's rights comes with imperative concepts of "good" and "bad" which apparently comes from the Islamic context of where they are culturally being nourished.

Here are some of the children's discourses indicating what has been claimed above:
"All the people are God's creatures, so they are all equal." (Ana, 10 years old girl) "God doesn't like people to fight; this is what evil likes and God will get upset!" (Nazanin, 8 years old girl) "God created us to be friends and not to fight." (Mina, 9 years old girl) "If we do cruel things to other people, God won't like us anymore." (Saba, 7 years old girl) "We have somehow in our divine gift book about people's rights. It says that we have to be nice to others and not to fight with other people so God will reward us." (Tooran, 9 years old girl)

Teacher's discourses also show a considerable tendency to rely on Islamic culture in recognizing children's rights. Not only some teachers perform some Islamic practices in the classroom like praying before starting the course, etc., but also many of them mentioned Islam as a rich source for the rights of children:

\begin{abstract}
"Islam has imaged the highest rights for the kids including the right to be respected, to be loved and treated nicely, to get their basic needs fulfilled: emotional needs and a need for socio-moral education." (Marzieh, $3{ }^{\text {rd }}$-grade teacher) "Islam has the best rules for human beings including the kids." (Hanieh, 3rd-grade teacher) "Islam has recognized the rights of the kids the same as the adults."(Mandana, $2^{\text {nd }}$-grade teacher)
\end{abstract}

\footnotetext{
${ }^{25}$ The two last dynasties (the kingdom) ruled over Iran from 1796 to 1978.
} 
Occurrence \#2: Another unconscious - or conscious to some extent-effect of Islamic context on the social representations of children's rights was the adults' definition of the "age of childhood". ${ }^{26}$ Some of our interviewees showed a tendency to have an Islamic view about the differentiation between girls' and boys' childhood age. Girls are supposed to be considered as "not a child anymore" after the age of 9 years old or at most the age of physical puberty, while the situation is different for the boys. The boys' age of puberty (and consequently the end of childhood) is at least 15 years old. This is obviously an Islamic-based definition of childhood.

People's understanding of the end of childhood comes only with the Islamic defined age of puberty while the age of 9 for the girls and 15 for the boys are supposed to be just considered as the age of spiritual maturity or beginning the spiritual practices for human beings even according to Islam regulations. So the ages of civil or criminal responsibility have been assumed differently regarding modern interpretations of Islam- Shari'a. (The modern interpretations of Shari'a will be discussed briefly further in the current article.)

Moreover, the Islamic and ideological educational system of Iran has also an undeniable effect on the Iranian religion-oriented understanding of human rights and "the good life". We will, here, take a look at the long tradition of the Islamic-ideological educational system in Iran, while at the same time, a modern and enlightened interpretation of Islam is also observable in Iranian contemporary society. These two factors will explain our observation of social representations of children's rights in elementary schools and will answer the question of why and how human rights social understanding of children and also teachers are significantly embedded in the Islamic concept of "the good life" and "the good human being".

\section{Step Three: Suggestions for Iranian Governance to Move toward a Better Protection of Children's Right to "Proper Education"}

In this third and final step of forming the critical legal essay, we now present our suggestions, the ones we hope to be useful for a child's rights advocacy and that could be applicable in Iran as a society with all its specific legal, cultural, and social features. Therefore, putting together the legal, empirical, and philosophical outputs of this inquiry so far, we conclude that the Iranian governance in the educational system could benefit from a change toward the Virtue ethical concept of "proper education" which seems to be a modern and contractual type of education adapted to the Islamic cultural context of this society. In this section, however, we will discuss this suggestion while separating two different aspects: 1. the suggestion for a change toward a modern and contractual authority in the educational system by using the tool of "contractual pedagogy"; 2. a link to the virtue ethic and its affection on the general educational policies to serve the Islamic cultural and political aspect of Iranian society.

\footnotetext{
${ }^{26}$ UNESCO Director-General, Dialogue among civilizations: the round table on the eve of the United Nations Millennium Summit - UNESCO Digital Library (New York: Round Table on Dialogue among Civilizations(2000), 2001).
} 


\subsection{First Proposal: Contractual Pedagogy to Overcome the Traditional mode of Education}

The "psychological modernity" in Mendel's terms is probably an inescapable event in Occident, but it is probably an inescapable event in the developing country of Iran too, which stands in contrast to the traditional forms of social structures. Having said that, it becomes rather logical to take the path to "contractual modernity theory" and transform it as a tool to renew traditional authoritarian forms towards the best support of children's rights in Iranian society.

\subsubsection{Characteristics of Contractual Authority in the Educational System}

Hereby, we first summarize the four mentioned characteristics of a contractual pedagogical authority in Violaine Lemay's work. We then signal the presence or absence of them in the Iranian education system according to our observations. Although we came above to the conclusion of lacking such socio-psychological modernity in our investigated field, we also have noticed some practices that already seem to be open to this movement without knowing it.

a. Negotiation

According to the theory of "contractual modern form of authority" (Lemay 2005) presented in previous sections, negotiation has been referred to as a common principle in modern forms of relationships between the authority holders and subordinates, as it allows the latter ones to express their idea and choices and builds up a positive identity for them by providing a contractual context in which the subordinates' rhythm is also taken in count in any development of a project.

This is what we have observed in the students of Iranian elementary schools in different ways. They try to show their identity by breaking the rules of the school. ${ }^{27}$ They have never been negotiated about ruling the school's environment and are not even welljustified about what they are obliged to do, so they become resistant in accepting the regulations. The students usually find the school's regulations unjust and unfair because they have received them as an imposing obligation with no regard for children's need of being useful and worthy of consideration and counterpart.

\section{b. Sharing the Autonomy}

In the continuity of the principle of "negotiation", the principle of "sharing autonomy" will be applicable. It means that once the opinion of subordinates has been consulted, they should get participated in making decisions in the cases where their own life and interests are involved. This is either because of a pragmatic point of view or a

\footnotetext{
27 “'Everything Is Forbidden at School, but We Still Do!': The Common Refusal of the Legitimacy of School Authority/Regulation", Supra note 1 at 219-220.
} 
moral one that indicates the contractual relationships more efficient/functional or being just/moral. From a traditional point of view, only the superordinate of a professional relationship possesses useful knowledge (the doctor, the teacher, the psychologist, etc.), but from this "modern authority" point of view, both parties possess one: the under ordinate is the only one to know which are his personal preferences, habits or experiences that one has to know to achieve goals of the relationship.

In our field, we had the feeling that the children's desire for a cooperative type of teaching was a kind of aspiration for them. We have discussed ${ }^{28}$ what the students have experienced as a happy education by which we mean providing a cooperative environment in the classrooms to improve children's enthusiasm to get involved in the process of learning which is not only more efficient in the sense of pedagogical aspect but also more in accordance with the children's rights to "proper education."

\section{c. Communication of Knowledge}

Communication of knowledge is another common factor in modern human relationships, especially in subordinate relationships. It includes a kind of pedagogical contract between the two interactors, i.e. there should be communications in all the information and methods of acting without considering the age or level of comprehension of the parties. In education science, specifically, the teacher should explain and clarify the reasons for her/his choices even if the clients in this contract are the children. It is something different than the traditional task of the teacher which includes passing the information to the learners. It stays a vertical power relationship, but the verticality is voluntary reduced. Then, it is more horizontal, as long as communicative connection reduces the "imposing type", transforming it into a more consensual form of transferring the knowledge to the students (they are still in compulsory school, but the feeling of it is softened.)

The presence or absence of this principle in the Iranian educational system depends again on the children-adult relationship in this sphere. It seems that although the teachers claim to be aware of the modern methods of teaching in the classrooms, there is still a gap between what they theoretically know and what practically happens. This is while students usually complain about the rules that they do not understand the rationality or they do not find them fair and they are not well justified about the established cameras in the school area. We could not consider the student-staff relationship following a communicative model either in sharing the information/ justification about the rules of the school or in respecting children as the right holders to be a part of the pedagogical contract.

\section{d. Sharing Responsibility}

The principle of sharing the responsibilities, which includes the explanations of reciprocal obligations (or roles), belongs to both the teacher and the students; as

\footnotetext{
28 "Happiness as the Aim and Method of the "Proper Education", Supra note 1 at 203-204.
} 
it proposes the teachers and school's staff to make their goals and methods clear and justified (for the students and themselves) as well as explaining the students' tasks and obligations.

In sum, the clarification of the roles contains a clear atmosphere in the educational system in which the tasks and responsibilities are explicitly defined regarding the clear goals and methods of the education while considering the different cognitive capacities of the task holders. This is what we barely found in our observed field. The elementary schools of Iran seemed to be more consistent with the traditional type of system.

\subsection{Second Proposal: Virtue Ethics Theory to adapt the Modern Education with Islamic Cultural Context}

As it has been observed and discussed extensively in the earlier sections, the Islamic aspect of Iranian society is not detachable from the social representations of children's rights in the educational sphere. Accordingly, the suggested paradigm shift — from a traditional form of authority in the educational policies to a "contractual" one which is compatible with the psychological modernity_-, could not become a piece of well-fitted advice for Iranian society unless we make an anchorage to Islamic cultural context of this field. We have to serve the oriental features of this part of the world rather than adopting just a universal and occidental model that might fail to respond to the needs of these specific people.

Therefore, while looking for a suitable form of educational policies for Iran, we will look up Islamic education's aims and features with its connections to the teachings of virtue ethics. And then, through the political views coming from virtue ethics, we try to suggest public policies for the Iranian governance in the educational system.

\subsubsection{Islamic Education connected to Virtue Ethics as an Aim-Talk for Iranian Educational System}

We propose here that our conceived virtue ethical concept of the proper education is very well applicable in the society of Iran especially because of the Islamic embeddedness of the concept of the good life in our observed field. Looking at the philosophy and aims of Islamic education approves this approach.

An analysis of the philosophy of Islamic education states that "(i) aiding individual development, (ii) increasing understanding of society and its social and moral rules and (iii) transmitting knowledge" (Halstead 2004, pp.522-523) are three main objectives of Islamic education and if they might not be seen in many Islamic countries in practice, it is mainly because of the influence of western ideas or failing in implementation of compatible methods.

These aims could be observed very similar to the virtue ethics approach in education which intends to develop virtuous characters who besides the attempt for internal growth, are also devoted to developing their community toward a moral society. 
One could see the same rationality in the aims of education in Islam that regarding the First World Conference on Muslim Education held in Jedda-Mecca (1977) is "to produce a good man. [And] the ultimate aim lies in the realization of complete submission to Allah as the Creator, on the level of the individual, community, and humanity at large." (Yasin \& Jani 2013, p.3)

It could also be found in the philosophy of great Muslim thinkers like the 11thcentury Iranian theologian al-Ghazali and the 16th-century Turkish moralist Kinalizade, whose writings about Islamic education have been compared by J. Mark Halstead (2007, p.290) as quoted below. Let's observe that their conceiving of Islamic education is rather similar to the conception virtue ethic version of the "proper education":

"Both scholars emphasize the role of parents in the moral upbringing of their own children, both consider the child to be a tabula rasa on which good habits can be imprinted, both discuss the tendency of young children to imitate others and hence stress the importance of encouraging good friendships and setting them a good example. Both discuss the importance of learning discipline, self-sufficiency, and restraint, as well as generosity, politeness, and humility. Both agree that teachers should genuinely care about their pupils, avoid excessive harshness, and encourage games as a way of relaxing and unwinding (as well as a way of familiarising them with the concept of rules)."

Islamic philosophy of education aims to make a balance between the three dimensions of sense, mind, and religious faith to achieve human values in reality. So, Islamic education is aware of the significance of developing rationality and personal autonomy in attaining human virtues. While Quran, as the main source of Islamic teaching, advice repeatedly to think rationally and avoid blind faith even in accepting the basic rules of Islam, the Islamic philosophers and authors have also focused on the role of knowledge, science, and epistemology in achieving the ultimate truth:

"This education believes that human life progress is the duty of every Muslim. Progress achievement is done by the activism of the three dimensions, namely epistemology production ought to rely on experimental and rational methods, while the ethical dimension constitutes a reference and authority to every human activity. Thus, Knowledge and science had a functional role which comes to achieve a better life for humankind." (Rayan 2012, p.156)

Therefore, a short look at the Islamic education that is derived from the Islamic ethics and rationality reveals very many common points with the aims of virtue ethics theory derived from ancient Greek philosophy. Both of them aim to educate "a good man" to achieve the final goal of "the good life". In both, the means of this moral character education is developing rationality in order to possess virtues. Knowing these similarities, now we can turn to the political aspect of virtue ethics theory to contribute to the educational public policies of Islamic Iran. 


\subsubsection{The Contribution of Virtue Ethics in Educational Public Policies of Iran to Achieve the "Proper Education"}

In this last step of our critical essay, we will look for the political aspects of virtue ethics theory to help the Iranian governance in improving toward the protection of children's right to "proper education". As the public policies of Iranian governance have been discovered to be suffering from a traditional form of authority (earlier in the path of our critical discussion) which needs a reform toward a modern and contractual one, therefore, the main contribution of this essay to help the Iranian governance will be in the field of public law which hopefully decreases the problems of educational public policies of this country.

To briefly access the political philosophy ideas of virtue ethics, we would like to refer to the master thesis of the author of these words ${ }^{29}$, which has been a philosophical attempt to derive a theory of state from the moral philosophy of virtue ethics. The next lines are taken from this work.

Virtue Ethics and the State (2011): In this thesis, the researcher first determines the three main principles of virtue ethics theory as virtues, practical wisdom, and eudemonia or happiness. Then through a vast moral philosophical study from ancient Greek to the contemporary virtue ethics philosophy, she concludes that the aim of happiness could be attained only through the possession of a rational capability named practical wisdom which by itself guarantees the moral choices or virtuous characteristics. Then by reviewing the political philosophy literature of virtue ethics, including the ideas on liberty (the virtue ethical approach to the positive liberty), the common good (the virtue ethical approach to the communitarianism), and the human flourishing or the good life (the virtue ethical approach to the perfectionism), finally the author suggests a model of state for the virtue ethics approach to the governance. This model of state is based on the communitarian characteristic of human beings i.e. the character perfectionism is achievable through social activities and exercising the internal virtues by positioning in similar external situations. ${ }^{30}$

This suggested virtue ethical state, then, stands on two basic principles, virtues, and practical wisdom, that failing to adhere to each of them will end up an inconsistency and internal paradox. Among the socio-political virtues that should become the principal virtues of the state are Autonomy (a personal virtue that is developed under the protection of positive liberty) and Toleration (a social virtue that causes a pluralistic society as an appropriate field for improving self-flourishing). The practical wisdom, however, could be conceived as the social aspect of the virtuous character that employs the internal practical wisdom toward the external flourishing of the community. Therefore, a liberal state (either

\footnotetext{
${ }^{29}$ The citation of this master dissertation has been removed due to the journal's anonymity policy.

${ }^{30}$ See: David McCabe, “Joseph Raz and the contextual argument for liberal perfectionism” (2001) 111:3 Ethics 493-522.
} 
a Political Liberalism ${ }^{31}$ or a Perfectionist Liberalism $\left.{ }^{32}\right)^{33}$ with the main task of education (to improve the practical wisdom autonomous characters) could be imagined for a virtue ethical state.

Having reviewed the political theory of virtue ethics, we can now adapt such a model of the state in the public policies of Iranian governance regarding the protection of children's rights to "proper education". A virtue ethical educational system, then, would have to adhere to two central principles: promoting autonomy/toleration and improving practical wisdom (moral rationality). According to the previous discussion on the political philosophy of virtue ethics, the educational policies of such a state would aim to provide the children with an open future and a flourished character.

Although some authors believe that the unavoidable distance between Islamic and western liberal conceptions of education is "ultimately unbridgeable" (Eaton 1982, p.114), but there is a conscious stream of thinking in Iran that seeks the modern democratic principles without surpassing the Islamic culture. This trend is known with the thoughts of Abdulkarim Sorush, the well-known figure among Islamic intellectuals and philosophers at the forefront of the reform movement in post-revolutionary Iran (Vahdat 2003). He emphasizes the role of reasoning and rationality in modern Islamic interpretations and therefore does not find it contradictive with the modern rationality of science and democracy:

“... a necessary prerequisite to the democratization of the religious government is to make religious thought more flexible by elevating the role of 'reason' in it; that is not individual but the collective reason, arising from the participation of all and benefiting from humanity's experiences; and this is possible only through democratic means." (Soroush 1994, p.280)

Even though the Islamic State of Iran is not neutral about the best form of life and promotes the Islamic values in the society by its nature, our suggested model of education

\footnotetext{
${ }^{31}$ Political Liberalism has been defended by John Rawls and Martha Nussbaum (a contemporary virtue ethics philosopher). Refer to:

John Rawls, Political Liberalism (Columbia University Press, 2005).

Martha C Nussbaum, "Perfectionist liberalism and political liberalism" (2011) 39:1 Philos Public Aff 3-45.

${ }^{32}$ Perfectionist Liberalism is defended by Joseph Raz. Refer to:

Francesco Biondo, "Two types of liberal perfectionism” (2005) 18 Ratio Juris 519.

McCabe, David. "Joseph Raz and the contextual argument for liberal perfectionism" (2001) 111:3 Ethics 493-522.

Joseph Raz, The Morality of Freedom (Clarendon Press, 1986), Google-Books-ID: u3FZzAPkf08C.

${ }^{33}$ While the perfectionist liberalism believes in the priority of a form of life for which the liberal states have the duty of providing positive liberty (not being just neutral about all the values but also putting efforts in promoting the social value meaning autonomy in the contemporary world), the Political liberalism promotes the virtue of toleration by accepting that all the forms of life and religions could claim their own priority but have to respect and tolerate the other approaches. However, both perfectionist and political liberalism focus on autonomy as the principal virtue that would result in the ultimate good life or happiness for the human being.
} 
promotes these virtues only to some extent that does not limit the free circulation of information and liberty of expression of other forms of life or religions. Therefore, due to the result of such a pluralistic society, the children would have the chance to get informed about all the choices of their life and by benefiting an autonomous character, their right to an open future and self-flourishing would be served.

This education also benefits the contractual approach to the authority in the relationship of adults-children and employs the modern psychological methods to develop moral characters with the most probable mental health. The character education methods which are based on developing the character strengths with constructive responses and with the approach of a human rights-friendly school would be suggestable in this educational policy.

Regarding the suggestions of this critical legal essay, thus, the Iranian governance could improve toward better protection of children's right to "proper education", if the Iranian public law moves toward more political liberalism which especially in its educational public policies aims to promote autonomy and toleration among the children who will build an open future for themselves and their community. These children will benefit from the fruit of enjoying the right to "proper education" regarding the very own cultural social features of Iranian contemporary society.

\section{Conclusion}

To find a piece of advice for Iranian governance to get improved in respecting children's right to proper education, we put together, in this article, the results of a classical legal study on the internal legal system of Iran, the philosophical outcome of a research on virtue ethic state as a proper model of governance for Islamic countries like Iran and the empirical results presenting the social representations of human rights in Iranian educational system.

We started by looking critically at the legal and educational system of Iran regarding the protection of children's right to proper education. In this step we pointed out that this socio-legal system suffers from three significant problems: 1) a deficiency in the public policies of Iranian governance in children's affairs and the social inertia problem of the persistence of an obsolete and counterproductive form of educational authority. 2) a traditional interpretation of Islam also affects the legal and political approaches of the Iranian state. 3) a traditional mode of authority in the educational system of Iran that is not consistent with the psychological modernity of the children-adults relationship. Then we looked for the socio-cultural features of Iranian society which should be considered for any potential improvement. Three significant notions were detected in this regard: 1) a pro-democratic social collective hope and a high desire for human rights implementation, starting from the elementary schools; 2) The Islamic educational system in Iran that makes the comprehension of human rights inseparable from Islamic culture in this field and 3) the modern and enlightened interpretation of Islam that Iranian intellectuals find it more consistent with international human rights regulations. Therefore, one stays optimistic about the openness of this developing country, as the irresistible desire of people for 
entering the world of democracy and human rights seems to be an open window through a paradigm change. In our second step, we offered the result of an experimental study on the human rights social representations in Iranian elementary schools that actually confirmed all the difficulties and socio-cultural features mentioned in the literature review. Being equipped with all this information, in the third step, we looked for final advice for Iranian governance to get improved in the condition of children's rights in the educational system, which will be a very domestic right to "proper education". First of all, a paradigm shift from the actual traditional form of authority into a modern "contractual" one, in the sense that Lemay means and which is compatible with the modern psychology of children is suggested.

Having reviewed the political philosophy and the suggested theory of virtue ethics state and by reflecting the central public principles of such a government into the educational public policies, the conclusion was to advise the Iranian governance to approach a liberal form of policies that despite keeping its chosen main religion as Islam and developing the Islamic virtues, will focus on developing the two critical virtues of autonomy and toleration. By this policy, the Islamic and virtue ethical aim of "proper education" will be served to improve the condition of the children's "right to an open future" and "the right to character flourishing".

By these three steps of interdisciplinary critical rationality, we tried to create a form of legal writing which is called by Jean-François Gaudreault-DesBiens as "faire du droit". We did it to help the Iranian governance in improving towards better protection of children's right to "proper education". For all these reasons presented above, the current article is not "any law article on children's right to education" as it is not a "one size fits all": it is one especially "tailored" for contemporary Iran.

\section{BiBLIOGRAPHY}

Akbari, Mohammad Ali. Iranians'desire to democracy (2003).

An-Na'im, Abdullahi Ahmed. "Human Rights in the Muslim World: Socio-Political Conditions and Scriptural Imperatives - A Preliminary Inquiry" (1990) 3 Harv Hum Rights J 13-52.

Bashiriyeh, Hosein, The transition toward democracy, Negahe Mo'aser publication, 2008

Bielefeldt, Heiner. "Western' versus 'Islamic' Human Rights Conceptions? A Critique of Cultural Essentialism in the Discussion on Human Rights" (2000) 28:1 Polit Theory 90-121. https://doi.org/10.1177/0090591700028001005

Biondo, Francesco. "Two types of liberal perfectionism" (2005) 18 Ratio Juris 519. https:// doi.org/10.1111/j.1467-9337.2005.00313.x

Bostani, Fateme. Children's Right to "Proper Education" in Contemporary Iran: A critical Legal Essay with an Ethical and Empirical Approach towards Improving Iranian Governance (Ph.D. Thesis, Université de Montréal, 2019) [unpublished]. 
Bostani, Fateme. Virtue Ethics and the State (Master Thesis, Allameh Tabatabaii, 2011) [unpublished].

Cheddadi, Abdesselam. Ibn Khaldoun (Casablanca: La croisée des chemins, 2016).

Eaton, H G. "Knowledge and the Sacred" (1982) 26:3 Islam Q 138-148.

Gaudreault-Des Biens, Jean-François. 'De l'essai En Droit, Ou Du Droit à l'essai Dans La Doctrine?” (2010) 65: 2 Revue interdisciplinaire d'etudes juridiques 135-77. https://doi.org/10.3917/riej.065.0135

Ghaffari, Mohammad Reza \& Mohammad Hosseini. "Reconsidering the social policies about children in contemporary Iran" (2015) 47 J Sociol Stud 177-210.

Halstead, J Mark. “An Islamic concept of education” (2004) 40:4 Comp Educ 517-529.

Halstead, J Mark. "Islamic values: a distinctive framework for moral education?" (2007) 36:3 J Moral Educ 283-296. https://doi.org/10.1080/03057240701643056

Homayoun Katouzian, Mohammad Ali, Tyranny, Democracy and Nationalist Movement, Tehran, Markaz Publication, 1993

Jahanbakhsh, Forough. Islam, democracy and religious modernism in Iran, 1953-2000: from Bāzargān to Soroush (Brill, 2001).

Jalaiipour, Hamidreza. "Theoretical thoughts on the democracy in contemporary Iran" (2004) 23 Lett Soc Sci J 191-200.

Ka'r, Mehrangiz. "The essence of modifying the constitution in order to fulfill the children and women' s rights: an interview" (2005) 64 J Thoughts' Reflect 97-102.

Kaufmann, Jean-Claude, L'entretien compréhensif (Paris: Nathan, 1996).

Lemay, V et al. "Personalized Medicine: Interdisciplinary Perspective, World Tidal Wave, and Potential Growth for the Emerging Countries" in Prog Chall Precis Med (Elsevier, 2017) 301. https://doi.org/10.1016/B978-0-12-809411-2.00016-7

Lemay, Violaine. "Mutations contemporaines des représentations de l'enfant par le droit" in Représentation L'enfant Devant Trib (Montreal: Themis, 2009) 3.

Lemay, Violaine. Un contrat pédagogique: l'entente sur mesures volontaires dans l'application de la Loi sur la protection de la jeunesse (PhD Thesis, Université de Montréal, 2005) [unpublished].

Mansoori Boroojeni, Mohammad. Children's General Primary Education: a study of Iran and US legal system according to human rights provisions (Mater thesis of public law, Shahid Beheshti University, 2011) [unpublished].

Masood Haidari \& Jalaluddin Ghiasi, «The puberty criteria for the criminal responsibility in Sharia' and Iran's law », (2013) 9-32 Investig. Sharia Islam. Law 87-104.

Masoumeh Modavvar, «The problematic of children's rights in Iran and in the world », (2017) 1-13 Philos. Child 77-88. 
Matin-asgari, Afshin. "Abdolkarim Sorush and the Secularization of Islamic Thought in Iran",(Winter - Spring, 1997), 30: 1/2 Iranian Stud 95-115. https://doi. org/10.1080/00210869708701861

McCabe, David. "Joseph Raz and the contextual argument for liberal perfectionism" (2001) 111:3 Ethics 493-522. https://doi.org/10.1086/233524

MirFardi, Omid. “Considering Iran's criminal policy facing the children's prostitution in Iranian legal system and the second amended protocol to Convention on Children's Rights" (2017) 3:2 Polit Stud Law Figh'h 113-133.

Mojtahedzadeh, Pirouz. Democracy and Iranian Identity (Tehran: Kavir Publication, 2007).

Mousavi Chalak, Hassan. The essence of analyzing social policies regarding children (2015).

Nablia, Sahbi. La conceptualisation de la société civile islamiste selon Ibn Khaldûn: vers une première lecture du printemps arabe $(\mathrm{PhD}$ Thesis, Université du Québec à Montréal, 2011) [unpublished].

NazerZadeh Kermani, Farnaz. "Children's rights: a need for recreation" (2009) 2 Dadnameh J 38-42.

Not being child-oriented of current laws as the most important deficiency in protecting children's rights: an investigating report (IRIB NEWS AGENCY, 2018).

Nussbaum, Martha C. "Perfectionist liberalism and political liberalism" (2011) 39:1 Philos Public Aff 3-45. https://doi.org/10.1111/j.1088-4963.2011.01200.x

Parsapour, Mohammad Bagher \& Sousan Nourbakhsh. "The criteria for evaluating the best interest of the child in sharia', Iran's law and the convention of children's rights" (2015) 2:3 Islam West Law Comp Stud 1-28.

Ravanestan, Arezoo. "The effect of universal pro-democratic movements on Iran's state and people relationship" (2017) $22 \mathrm{~J}$ Int Investig 47-67.

Rawls, John. Political liberalism (Columbia University Press, 2005).

Rayan, Sobhi. "Islamic Philosophy of Education" (2012) 2:19 Int J Humanit Soc Sci $150-156$.

Raz, Joseph. The Morality of Freedom (Clarendon Press, 1986).

Sohbatloo, Ali. "Education in Ancient Iran" (2008) 231 Teach Dev J.

Soroush, Abdolkarim. Farbeh tar az Ideology [More Corpulent than Ideology] (Tehran: Serat Publication, 1994).

Soroush, Abdolkarim. Theoretical contraction and expansion of the shari'a, 11th ed (Serat Publication, 2009).

Syed Al-Naquib al-Attas. World Conference on Muslim Education 1977, Makkah: Aims and Objectives of Islam Education (Jeddah: King Abdulaziz University, 1979). 
Takmil Homayoun, Naser. "Forming the first state of educating children in Iran's Islamic period" (2002) 43 Farhang J 33-46.

Tamer, Yasin. Basic changes in Iranian education system before and after Islamic Revolution (Master thesis, Middle East Technical University, 2010) [unpublished].

UNESCO Director-General. Dialogue among civilizations: the round table on the eve of the United Nations Millennium Summit - UNESCO Digital Library (New York: Round Table on Dialogue among Civilizations (2000, 2001).

Vahdat, Farzin. "Post-revolutionary Islamic discourses on modernity in Iran: Expansion and contraction of human subjectivity" (2003) 35:4 Int J Middle East Stud 599-631. https://doi.org/10.1111/j.1088-4963.2011.01200.x

Yasin, F B R \& M Jani. "Islamic education: The philosophy, aim, and main features" (2013) 1:10 Int J Educ Res 1-18.

Zarean, Mohammad Javad. Islamic values and their reflection in the Iranian elementary textbooks: Islamization in post-revolutionary Iran. (Ph.D. Thesis, McGill University, 1998) [unpublished].

Zarei Matin, Hasan, Gholamreza Jandaghi \& Boshra Moeeni. "Considering and comparing the extent of structural learning in public and private schools of Qom in 20022003" (2003) 3:22 J Handl Cult 47-68.

Received: January $21^{\text {st }} 2021$

Accepted: April 29 2021 